\title{
Miranda
}

Revue pluridisciplinaire du monde anglophone /

Multidisciplinary peer-reviewed journal on the English-

speaking world

$11 \mid 2015$

Expressions of Environment in Euroamerican Culture /

Antique Bodies in Nineteenth Century British

Literature and Culture

\section{Dark Places : Ecology, Place, and the Metaphysics of Horror Fiction}

\section{Brad Tabas}

\section{(2) OpenEdition \\ Journals}

Electronic version

URL: https://journals.openedition.org/miranda/7012

DOI: $10.4000 /$ miranda.7012

ISSN: 2108-6559

Publisher

Université Toulouse - Jean Jaurès

Electronic reference

Brad Tabas, "Dark Places : Ecology, Place, and the Metaphysics of Horror Fiction", Miranda [Online], 11 I 2015, Online since 10 July 2015, connection on 08 September 2022. URL: http://

journals.openedition.org/miranda/7012 ; DOI: https://doi.org/10.4000/miranda.7012

This text was automatically generated on 8 September 2022.

\section{(c) (†) $\ominus$}

Creative Commons - Attribution-NonCommercial-NoDerivatives 4.0 International - CC BY-NC-ND 4.0

https://creativecommons.org/licenses/by-nc-nd/4.0/ 


\title{
Dark Places : Ecology, Place, and the Metaphysics of Horror Fiction
}

\author{
Brad Tabas
}

The world is increasingly unthinkable-a world of

planetary disasters, emerging pandemics,

tectonic shifts, strange weather, oil-drenched seascapes, and the furtive, always-looming threat of extinction. In spite of our daily concerns, wants, and desires, it is increasingly difficult to comprehend the world in which we live and of which we are a part. To confront this idea is to

confront an absolute limit to our ability to adequately understand the world at all-an idea that has been a central motif of the horror genre for some time. (Thacker 1)

1 Horror fictions are very much about ambiance, place, surroundings and environment. While lesser examples of the genre use stock scenarios like haunted houses, misty graveyards, and god-forsaken rock outcroppings, most of the finest pieces of horror writing explore the expression of place in highly specific and deeply innovative ways. Sometimes this engagement with place, as in the work of China Miéville, involves the invention of new and weird topographies, while for other writers, the places described are known regions and even seemingly familiar locales. For H.P. Lovecraft, it was the New England landscape, with its "vast and gloomy virgin forests in whose perpetual twilight all terrors might well lurk" (Lovecraft 1973, 60-61) that gave birth to Edgar Allen Poe and Nathaniel Hawthorne (and surely also to Lovecraft himself.) Jeff VanderMeer, one of the contemporary writers that I turn to at a later juncture, openly admits the importance of the Quinta da Regaleira in Sintra, Portugal as well as the Saint Mark's wildlife refuge in Florida as sources of inspiration. Nor is the expression of place in weird fiction restricted to a banal or artless preoccupation with describing places or alluding to hackneyed topoi (as the Gothic is sometimes accused of doing with its haunted castles and misty moors). Indeed, the most strikingly original aspect of the 
best weird fiction's expression of place is the ways in which it deforms or veers (in Nicolas Royle's finely nuanced sense of the term) our ordinary and often careless ways of talking about the environment into novel and arresting literary expressions.

Strangely enough, though, ecologically engaged critics have barely cast an eye towards this kind of writing. Lynch, Glotfelty, and Armbruster's recent The Bioregional Imagination: Literature, Ecology, and Place, devotes no chapter to horror writing and many to nature writing and regional literature. The same is true of Friedman and Waldron's Towards a Literary Ecology : Places and Spaces in American Literature. Surely the excuse for this oversight would somehow involve the notion of the natural and some form of insistence that horror does not deal with the natural but rather with the supernatural, as it is of nature and naturalism that the editors of these volumes speak when they explain the general literary strategies at work in the texts covered in their volumes. But as we will see, this overlooks and misunderstands the functioning of explorations of place in horror. Another possible justification for ignoring horror might involve the claim that all horror is set in generic locations, or perhaps it might suggest that it is preoccupied with ghosts and figments of the imagination as opposed to the depths of cosmic reality. But both of these objections, as we shall see, are quite shallow, quickly remedied and responded to via the reading of the highest examples of weird writing. Doubtless this disregard for the weird tradition also results from a somewhat blinkered conception of ecological criticism, one perhaps tied too closely to the idea of seeing literature as a means of transmitting information, and too married to the idea that evocations of place in literature ought to amount to a kind of cartography or landscape painting. But as we will see in what follows, weird literature can help us to develop an utterly different, if not less important, critical conception of the role of literature as prompting us to think deeply about reality of the places that we inhabit.

One problem with dismissing supernatural horror for its lack of 'naturalism' derives from a lack of appreciation on the part of naturalist writers and critics for the thoroughgoing idealism of their position. Naturalist writers and critics that confound realism and naturalism consistently confuse what Timothy Morton might call the natural and the Natural. The natural we might take to mean the reality beyond our minds, the things of the world in their relation with one another. The Natural, on the other hand, we might take to refer to this "outside" as it appears to reflecting subjects via the mediation of our cultural, scientific, and linguistic representations. As Timothy Morton has extensively argued in his Ecology Without Nature, one of the major weaknesses of ecological writing and in particular the critical literature on this writing has been its tendency to confound nature and Nature by engaging in what he calls "eco-mimesis" (Morton 2009, 81), essentially the confusion of representations of things with the things themselves; Kant described this as "transcendental realism" (Kant B 518). The point is not that there is there is no ultimate autonomous reality outside of our heads, but rather that the ideas and representations that we have about this reality, what we call "nature," are not identical with the real, and in taking them to be identical we precisely occult the real and so miss out on a deeper and perhaps more satisfying form of realism. In other words, the nature that we think, and think that we see, is a deformed version of the real, transformed by complex perceptual and cognitive processes. As Graham Harman has somewhat paradoxically put it: "nature is not natural and can never be naturalized" (Harman 2005, 251). A deeper realism, then, is not to be accomplished by focusing on what we call nature, but may paradoxically be 
achieved by lifting our gaze above or beyond nature to the real. Weirdly enough, this meta-natural realism, not in its reality but in its expression, often seems to evoke what we call the supernatural, if indeed we understand this word to designate something that stands opposed to, or beyond, the Natural.

The genius of horror and the supernatural precisely lies in its refusal to accept the Natural as ultimate or identical with reality. The very condition of possibility for supernatural horror is the acknowledgement of a gap between the real and the Natural or naturalized. Weird fiction (a term that I will here use as synonymous with horror, after the habit established by Lovecraft and S.T. Joshi) is weird or veered precisely as an expression of fidelity towards the real as that which demands a veering of, or deformation of, the natural towards what Jeff VanderMeer might call weird naturalism. ${ }^{1}$ Supernatural horror, in other words, should be of interest to ecologists precisely because it is realist, but not Naturalist. Realism of this type keeps eco-critics focused on things-in-themselves and not upon mere representations of those things. This demands a great deal of critical rigor, but it also yields a heightened attentiveness to both the text and the world that surrounds us, for few will deny that their senses have ever achieved such knife-edge sharpness as they do in moments when they confront the terrifying and unknown. Indeed, a higher awareness of this kind yields a very deep ecology, an ecology that is not merely aware of the interconnection of objects that are not human, but also of the strangeness and otherness of these objects and the places that their intermeshing generates. As Tom Sparrow's object-oriented re-reading of Levinas' ethics has suggested, attention to otherness orients us towards the opening of an authentically ethical relationship to our environments, since the otherness that we are attending to echoes the strangeness of other human beings that we normally attribute to their recognition-demanding capacity for spontaneous, and moral, actions. Therefore we are forced to see the world around us as radically independent of our own will and designs. Aside from allowing us to develop an ethical approach towards thinking about the otherness of places and objects, developing a mode of ecocriticism adequate to dealing with weird writing allows for the elaboration of critical and not dogmatic forms of eco-critical practice, since it is the gap between the real and the natural that opens the space for a criticism that does more than envision literature simply as a sweetened means for delivering the dry truths of scientific discoveries, but rather as an art that alludes to an all-important yet obscure reality to which we must learn to attend.

5 It is clear that the kind of realism at work in horror fiction is of a special kind that has little to do with what would ordinarily be called realism in literature. Borrowing a term from Graham Harman (2012), I call the realism of horror weird realism. Weird realism involves the insistence that there is a reality outside and beyond the senses, while at the same time claiming that this reality can, in occult and incomprehensible ways, interfere with and challenge our reality, altering it and transforming it in sometimes inscrutable, contingent, or weirdly super-Natural ways. In weird realism, the object outside experience does exist, and it exists wholly independently of our experience or even our logic. As Jeff VanderMeer, for instance, explains, with reference to his weird naturalism, we live on "an alien planet filled with incredibly sophisticated organisms that we only partially understand...our so-called smart-phones and other advanced technology is incredibly dull and primitive next to the diversity and intensity of other life on Earth". (VanderMeer 2014) Yet if we cannot, and do not, fully understand these sophisticated organisms, they can nevertheless affect or influence that experience and 
logic in ways that do not wholly make sense to us. Thus the real, while never fully present to our minds or our senses, appears to us as dark, weird, veered, or uncanny. Reckoning with the fact that reality is sometimes stranger than fiction, however, sometimes means accepting that the actual can be confounded with the delusions of an unhealthy mind.

6 As a literary strategy, this weirdness in part expresses itself in the supernatural, which is of course that which is veered or "off" with respect to what counts as the normal or natural. But it can also articulate itself in various rhetorical strategies aimed at either expressing the outside or repressing the almost automatic mechanisms of naturalization that interpose themselves between places and their representations. Very often, then, weird descriptions of place are indeed written about writing, their target being as much the critique of the forgetting of the real in naïve naturalism as it is the expression of reality in any straightforward sense. The product of these weird expressions of place is not knowledge, as in the case of science or naturalistic writing, but rather attunement, a straining after or intensified awareness of the presence of others that also relate, beyond our perceptions and cognitions, amongst themselves, and so form places. We might say that this is an awareness, and not a knowledge, of the weird reality of ecosystems.

$7 \quad$ It would be unnecessary to cultivate our awareness of these weird realms if reality itself did not possess this structure. Yet one of the most salient facts about life in what Paul Crutzen and a growing mass of social scientists, historians, and literary critics call the Anthropocene is precisely our growing awareness of the gap between the cosmos as it appears to us and its depths. ${ }^{2}$ We are all aware that the spring of 2014 was incredibly snowy to residents of the northeastern United States, and yet it was also the same period in which the American Academy of Sciences confirmed that the climate had already warmed by two degrees. We are all-I hope-disturbed by the fact that the juicy red tomato that we buy at the store is actually filled with carcinogenic pesticides. We know, thanks to work of cognitive scientists like Andrew Clark, that our perceived world is a reduction of the total background to a few selected signs, a world that differs in degree but not in kind from the famously reduced world of the tick described by Von Uexküll. We should not feel that nothing happens to the world when we turn on our cars, though we often do forget that this simple and seemly inconsequential act is responsible for adding invisible $\mathrm{CO} 2$ particles into our atmosphere. These are all, admittedly, gaps that are glimpsed between the Nature of science and the Nature of the lifeworld of ordinary perception, but they do remind us of the horrifying uncanniness of the cosmos, and the complicity of our ordinary ways of perceiving in the perpetuation of our collective ecocide. In sum, the fracturing of our world supports the weird realist speculation that there is more to the world than is dreamt of in our (naturalist) philosophy.

8 The following essay is divided into two parts. The first sections offer a compressed genealogy of the development of weird realist vision in the work of three writers of cosmic horror : Poe, Lovecraft, and Jeff VanderMeer. The latter half of the text, largely in dialogue with VanderMeer, explores more profoundly the interest of weird writing for thinking about and living in the increasingly horrifying and uncanny age that is the Anthropocene. 


\section{Poe and the Obscurity of Objects and their Connections}

9 Edgar Allen Poe's "The Fall of the House of Usher" begins with a description of a place and its effects upon a person. Poe is quite specific about the time and the ambiance, the specifics of his experience. It was "the autumn of the year," and the "clouds hung oppressively low in the heavens," he passed through "a singularly dreary tract of country," and he finally found himself "within view of the melancholy House of Usher" (Poe 199). Upon first sight of this place-this house so queerly described as not just inspiring melancholy in the viewer but as itself melancholic, the narrator remarks "a sense of insufferable gloom pervaded my spirit." The narrator then goes on to reflect upon the strange power of this place upon the person, wondering how the scene before him "the mere house, and the simple landscape features of the domain" "the bleak walls" "the vacant eye-like windows" "a few rank sedges" "a few white trunks of decayed trees" could so affect him, likening their effect upon him to the "after-dream of the reveler upon opium" in their "bitter lapse into everyday life," the "hideous dropping of the veil" (199).

The dread that pervades the narrator is not presented as a dream or delusion, but precisely as an encounter with reality. The choice of analogies brings this out, not only because the narrator associates the queer reality of the house with ordinary reality, with what most of us would call the real itself and not the drug-fueled daydream. The same inversion is suggested by the figure of the veil, a trope that, as Pierre Hadot has explored, was long used in alchemical and other occult circles to refer to the concealed secret orders of the natural world. The reason behind this replacement of the ordinary with the dream world is clarified by a nearly philosophical claim that is introduced in the lines that follow. Asking himself how and why this building so affects him, the narrator comes upon what he calls an "unsatisfactory conclusion," namely that there are "combinations of very simple natural objects which have the power of thus affecting us, still the analysis of this power lies among considerations beyond our depth"(199). Without denying that this line is indeed obscure, let us say that it is clear enough to open up a rather rich field of speculations into the metaphysical notions crucial to thinking about horror and place.

11 Horror writer and theorist Thomas Ligotti has suggested that human awareness of the alien nature of objects, the sensation that "the objects around them were one thing and that they were another," led to the birth of horror (Ligotti 1). It is the uncanny doubling of the objects of perception of this kind that seems to fuel Poe's imagination. All that appears to us as subjects is a unified object, that is to say, drawing on the Husserlian doctrine of intentionality, a discrete and unified entity as opposed to a bundle of discrete qualities. Objects surround us always, and they compose to a certain extent the most familiar elements of our existence. We might count amongst the objects-at least in the technical philosophical sense-all that we know via experience : houses, animals, floors, people. But though common, objects are obscure and sources of obscurity. Objects do not remain fixed when we encounter them, live with them, or even merely attempt to pick them up. Objects slip through our fingers in both a literal and theoretical sense, and when they do they reveal more of themselves to us, present us with new depths and concealed aspects, aspects of the object independent from any theoretical or practical grasp that we might have of them, but which might matter with 
respect to the combinations that they can compose. Even what seems most present to us, the objects around us, our surroundings, are apt to dupe us, to seem one thing and to actually be another. The chair in the corner of the room might turn out to be a statue made of Styrofoam. The girl staring at me from a window across the street might turn out to be a mannequin or a machine, as in E.T.A. Hoffmann's "Der Sandman". No object is ever revealed to us in its totality, each has another perspective from which it might be viewed, or a concealed otherness, and that is only speaking of the object from the viewpoint of a vision without dynamism. As Poe's countryman and near contemporary Emerson puts it, in his "Experience" :

I take this evanescence and lubricity of all objects, which lets them slip through our fingers then when we clutch hardest, to be the most unhandsome part of our condition. Nature does not like to be observed, and likes that we should be her fools and playmates (Emerson 20).

The lubricity of objects, particularly when they are seen in terms of their interconnections, allows us to acknowledge that the real may stand beyond the set of norms and regularities that we have up to this point understood to constitute the natural order. David Hume, one of the towering intellectual figures of the century preceding Poe's, brings this point out clearly in his Enquiry Concerning Human Understanding. According to Hume, "no object ever discovers, by the qualities which appear to the senses, either the causes which produced it, or the effects which will arise from it" (Hume 111). More to the point, without experience-something always in short supply, since future experience can always contradict past experience-we can never draw any "inference concerning real existence and matter of fact" from a simple encounter with an object. Following Hume, then, it is a real logical possibility that effects that seem totally fantastic follow from causes that we have a false tendency to consider as logically evident because they are concordant with past experience. Why, for instance, should one billiard ball necessarily impart its motion to another? "May I not conceive," writes Hume,

that a hundred different events might as well follow from that cause ? May not both these balls remain at absolute rest? May not the first ball return in a straight line, or leap off from the second in any line or direction? All these suppositions are consistent and conceivable (112).

13 All of these possibilities are conceivable, just as all sorts of supernatural effects are logically possible given the gap between reality and our representations of the real.

Metaphysically speaking, then, Poe's reflection on the obscure possibilities set in motion by certain combinations of objects opens up the way for an account of reality in which what we call the natural is but one interpretation of past possibility, and not in any way an expression of the ultimate nature of the real. Of course we are here speaking about a metaphysical possibility with respect to how we imagine reality, and this in turn yields a point of rupture between two different approaches to the writing of fiction, and indeed, to the reading of Poe. On the one hand, our inadequate hold on the real generates fictions that examine the mental state of individuals tortured by their obsessions with realities that do not exist, as seems to be the case, for example, in Maupassant's Le horla, and may merely be the case in Poe. This would be the tradition described by S.T. Joshi as "psychological horror" (Joshi 7). On the other hand, there is the school of writing perhaps most prominently exemplified by Lovecraft and his followers, "cosmic horror." In cosmic horror, madness is present, but this madness is generated by a violence exercised by "outer, unknown forces" (Lovecraft 1973, 15). The 
result of this encounter with the real is a deformation of the subject, but it is not this that interests the writer of cosmic horror; rather, it is the wild figures that that the imagination generates in its encounters with the real that interests the cosmic horror writer. The figure that expresses this real in Poe's "Usher" is the animated outside, not so much a world haunted by human ghosts, but a world in which rocks and stones have a kind of "sentience," a certain spontaneity that allows them to act outside of the conditioning of natural law, just as humans conceived as ethical agents are supposedly capable of doing. It is this animation that explains the queer lawlessness of descriptions of the house of Usher, the "wild inconsistency" between the "still perfect adaptation of parts," of the masonry "and the crumbling condition of the individual stones" (201). Yet if Poe's writing opens up to a sketching of the real as animate, and thus as a real that in many ways resonates with the kinds of neo-animism defined by certain ecological thinkers today (I am thinking in particular of Timothy Morton (2013) and Eduardo Kohn), his exploration in this direction is also limited by his focus upon the psychological aspects of horror. This tight focus on psychology was not shared by Lovecraft, however, who once wrote that he had no interest in "man's relations to man," but only our relationship to the "cosmos," or, as he added by way of clarification, the "background" and not the "earth" (Lovecraft 1995, 155) as it is understood by humankind.

\section{Lovecraft, (Non)locality, and Madness}

THE MOST MERCIFUL THING in the world, I think, is the inability of the human mind to correlate all its contents. We live on a placid island of ignorance in the midst of black seas of infinity, and it was not meant that we should voyage far. The sciences, each straining in its own direction, have hitherto harmed us little; but some day the piecing together of dissociated knowledge will open up such terrifying vistas of reality, and of our frightful position therein, that we shall either go mad from the revelation or flee from the deadly light into the peace and safety of a new dark age. "The Call of Cthulhu" (Lovecraft 2008, 201)

Lovecraft's interest in the "background," what in the above citation from "The Call of Cthuhlu" he terms the "terrifying vistas of reality," is clearly attested to by his extreme attention to place and setting in his writing, his frequent indulgence in what must be considered the weird equivalent of verbal landscape painting. That said, there is very little in Lovecraft's descriptions of place that corresponds to the kind of ecomimetic rendering of the landscape that Don Scheese has insisted is central to nature writing. As Lovecraft's almost Heideggerian opposition between "earth" and "background" makes clear, his interest is in deeper and weirder topographies, not the world as it appears to us as we normally experience it, but the world as it is in its ultimate and deeper dimensions. ${ }^{3}$

Lovecraft's evocations of place, in what S.T. Joshi has called Lovecraft's "topographical imagination" (Joshi 7), are dedicated to disrupting our normal sense of being at home in the world. They do sketch out and allude to a reality that is supposed to be more ultimate than our own-and in this way they remain weirdly realist-but they as frequently or simultaneously serve to point out the chinks in our "placid island of ignorance." Lovecraft's writings set up almost Platonic ladders of mediation between narrators and the tales themselves, thereby introducing the specter of psychology and all of its associated distance-taking from the real. Nevertheless, the mind is here 
introduced in such a way as to render the real all the more horrifying, since the mind is seen as blocking us from seeing what is actually there. In Lovecraft it is never madness that engenders the experience of the real, but rather the encounter with the real that provokes fits of madness. Madness is thus the testament and seal of having experienced the real. In "Dreams in the Witch House," for instance, we are first confronted with the conundrum of whether Walter Gilman's dreams cause the fever or the fever the dreams, but we are then told that both alternatives are insignificant, for "behind everything crouched the brooding, festering horror of the ancient town, and of the mouldy, unhallowed garret gable where he wrote and studied and wrestled with figures and formulae when he was not tossing on the meagre iron bed" (Lovecraft 2008, 358). The background here is the foreground, or more properly, is a character, animate, "crouched," "brooding," "festering" (358). Moreover, as an animate being, the place is unaccountable, granted will, spontaneity, and the capacity to be acknowledged and to demand acknowledgment.

Yet if the background is a real being, an autonomous actor, the depiction of the place provided to us by Lovecraft via Gilman tells us as much about our limits with respect to our becoming aware of places and their populations as it does about the actual character of the old house. We are first told, for example, of "the sinister scurrying of rats," the "creaking of the hidden timbers in the centuried house," but also of sounds that are alluded to but not properly expressed, "unexplained sound," and indeed "certain other fainter noises, which he suspected, were lurking behind them"(358). Within the context of the tale, it is important to note that we will soon discover that the seeming rats are not quite rats, but rather rat-like beings with human hands for paws, which is to say that our apparent identification of the sounds as rat-sounds is itself undone, itself part of the mechanism of consciousness that we humans rely on, but which can be fallible at any instant. Meanwhile, quite aside from this description of ambient noise that turns out to be erroneously familiar, part of the description turns on sounds that are inexplicable and hardly to be signified, and also sounds that are only suspected (it turns out rightly), but unheard.

18 As a means of expressing place, then, Lovecraft constantly steps over the boundaries of our perception, vaguely hinting to us the details of an outside or ultimate reality, while at the same time rendering us acutely aware of the finitude of our grasp on the real. In Lovecraft's early work, such as for instance in "The Music of Erich Zann," the relationship between mind and world, text and real, is articulated through a confounding of our sense of place and time. This results in our inability to locate or cognitively situate a place via a narrative about a street that the narrator cannot find even after having "examined maps with greatest care," even when he has "delved deeply into all of the antiquities of the place" and has "personally explored every region, of whatever name, which could possibly answer to the street"(58) that he knew as Rue D'Auseil. Surely we are tempted to find the un-localizability of the Rue D'Auseil as evidence of its purely fictive nature, as a kind of subjective delusion of the narrator, but this reduction of the street to fiction is in no way justified, since its existence outside place and time, as weird as it seems, actually can be read as serving as a proof of its transcendental reality. At least since Kant, and quite explicitly since Schopenhauer, it has been theorized that it is us who "represent things as extended," which is to say that independently of our representations, "nothing extended can be present" (Schopenhauer 20). In other words, real things, like the Rue D'Auseil, are in themselves outside of time and space as we represent and understand these 
transcendental intuitions. Significantly enough, the Rue D'Auseil is almost-but not quite-readable as "street at the threshold" (Rue d'Au Seuil), a name which perfectly corresponds to the metaphysical status of the place named both in terms of what it suggests and what it does not confirm, namely the real status of the Rue d'Auseil as a liminal place, something that hovers between being simply unreal and the impossible coming-to-presence of the ultimately-extensionless real.

of course, one of the problems with positing the real as outside of time and space is that it renders expression difficult, since language itself expresses things in terms of temporal and spatial relations (verb tenses and prepositions). Rather than expressing or sounding the reality of the Rue D'Auseil, then, "The Music of Erich Zann" can go little farther in its description of reality than presenting us with an enigma, a place on the threshold of being on the threshold. In Lovecraft's later work, however, we encounter a richer strain of weird realist writing that bears us upward on a ladder of degrees of spatiality. In the abovementioned "In the Witch House," for instance, we read that Gilman lives in a room of "good size but of queerly irregular shape ; the north wall slanting perceptibly inward from the outer to the inner end, while the low ceiling slanted gently downward in the same direction" (360). Considered closely, this description is much weirder than one is prepared for. What, after all, is meant by the outer and inner ends of the north wall ? How can a ceiling slant downward in the same direction that a wall slants outward? Is this not somehow a confounding of the vertical and the horizontal ? We find similar weird spatialities in the "Call of Cthuhlu," where we are told of something "like a great barn-door" but which seemed to ambiguously lie "flat like a trap-door or slantwise like an outside cellar-door" (223). At another point in the same tale we discover that "the geometry of the place was all wrong," that the "relative position" of everything seemed "phantasmally variable" (223). What is going on here? It seems that we are encountering things that shatter all knowable categories. Yet at the same time, these texts are peppered with references to Einstein, Planck, Heisenberg, and Riemann. Alongside these names we find references to non-Euclidean geometry and space-time, weird theories explaining

possible freakish curvatures in space, and of Theoretical points of approach or even contact between our part of the cosmos and various other regions as distant as the farthest stars or the transgalactic gulfs themselves-or even as fabulously remote as the tentatively conceivable cosmic units beyond the whole Einsteinian space-time continuum. (363)

Of the weird geometry of the room in the Witch House we are told that the "the odd angles" seem to have "a mathematical significance" (360). In the "Call of Cthulhu," we are told that the geometry of the place "was abnormal, non-Euclidean, and loathsomely redolent of spheres and dimensions apart from ours" (222). When we look at diagrams attempting to render non-Euclidean or Reimanian space visible, we recognize that it is exactly these weird dimensions of the real that Lovecraft has in mind in his contorted phrases. In short, the weird realism of Lovecraft's writing gains depth as it tries to render scientific or mathematical realities present to us in and through the limited means of ordinary language and perception.

The point is not that Lovecraft is simply trying to describe the world as it is seen by science, within a language and for a subjectivity adapted to describing what Wilfred Sellars (1963) has called the "manifest image" of the world. For Lovecraft, weird fiction must always go beyond the logical and the known, and that is to say beyond mathematics and science. ${ }^{4}$ The real point has more to do with the ways in which our 
scientific knowledge of these deeper dimensions of reality already humiliate us, already demonstrating that our ordinary reality is delusive, thus opening up the possibility of a speculative sounding of depths that will be yet more real, and that is to say yet less idealized, less formed, as it were, to correspond to the limited and limiting spatial and temporal capacities of our brains.

Lovecraft's weird realist artistry does not end with his manipulations of time and space. $\mathrm{He}$ is arguably at his best when he veers close to what might seem to be apparently normal eco-mimetic writing, namely his weird regionalist evocations of the Miskatonic region, a place that in many ways seems like his native New England, and which within his fictions is precisely located in an indefinite proximity to Boston and other known locales. In "The Dunwich Horror," the first paragraph of the tale is thus an almost ordinary description of travelling a New England country road:

When a traveller in north central Massachusetts takes the wrong fork at the junction of the Aylesbury pike just beyond Dean's Corners he comes upon a lonely and curious country. The ground gets higher, and the brier-bordered stone walls press closer and closer against the ruts of the dusty, curving road. The trees of the frequent forest belts seem too large, and the wild weeds, brambles, and grasses attain a luxuriance not often found in settled regions. At the same time the planted fields appear singularly few and barren; while the sparsely scattered houses wear a surprisingly uniform aspect of age, squalor, and dilapidation. (264-265).

Here everything seems as if we are in some known region, here everything seems ordinary, even if the names correspond to places that do not actually exist. But if they do not exist, they could, or even could have, since the names used come from real places in Old England, and thus seem familiar even in their distance from the actual and known New England. As those of us who have visited or lived in Vermont or Western Massachusetts may acknowledge, when reading Lovecraft's descriptions it is easy to feel lulled into thinking that we know this place, that we are actually travelling through the New England that we know, a world with which we are familiar and at home. But as the description goes on, we seem to cross over a threshold; Lovecraft marks the passage with a "rise in the road" that brings "the mountains into view above the deep woods." It is here that the first truly weird things appear : "The summits are too rounded and symmetrical to give a sense of comfort and naturalness" (265). Here what is stretched is not so much language-it is possible to imagine mountains as rounded-but precisely our pretension to know the world. Rather than trying to describe a real that does not fit within our ordinary faculties of representation and perception, Lovecraft here presents us with a real that is, as it were, too rational. It is as if he is suggesting that the very idea of circumscribing the real with the rational is bound to fail, since the very representation of the real when it is presented as geometrically rational is absurd, as absurd as would be a field of quintessentially identical dandelions, perfectly similar maple leaves, or ontologically indifferent cattle. And yet these things are the real, as reality is thought using ordinary language, scientific models, and 'healthy' rationality. Therein is expressed one of the terrors of our current situation, our deep awareness of the looming environmental crisis coupled with our awareness of the ways in which the limits of our minds hinder our every attempt to master or rationally model the world around us. Rather than becoming masters and possessors of nature, we slowly realize that we are possessed by nature, and that nature, for want to a better word, is possessed, ready to annihilate us for the unthinking ways in which we have tried to impose our mark upon the real. 


\section{Annihilation and the Weird Ecosystems of Area X}

Some types of omissions made my mind itch as much as more explicit offerings. One journal, half-destroyed by the damp, focused solely on the qualities of a kind of thistle with a lavender blossom that grew in the hinterlands between forest and swamp. Page after page described encountering first one specimen of this thistle and then another, along with minute details about the insects and other creatures that occupied that microhabitat. In no instance did the observer stray more than a foot or two from a particular plant, and at no point, either, did the observer pull back to provide a glimpse of base camp or their own life. After a while, a kind of unease came over me as I began to perceive a terrible presence hovering in the background of these entries. I saw the Crawler or some surrogate approaching in that space just beyond the thistle, and the single focus of the journal keeper a way of coping with that horror. An absence is not a presence, but still with each new depiction of a thistle, a shiver worked deeper and deeper into my spine. (VanderMeer 2014 b, 114)

Jeff VanderMeer openly admits that the setting for his recent novel Annihilation is the Saint Marks National Wildlife Refuge. It is perhaps for this reason that much of the novel, which he himself has described as "weird nature writing" (2014 c), recalls traditional nature writing in its content and its form. The narrator of the text is a biologist and many of her place descriptions are dotted not only with descriptions of particular flora and fauna, but also with extensive discussions of ecosystems, habitats, and taxonomy. Yet there is also a weirder, deeper dimension to VanderMeer's writing. As in the text above, he seems to look too closely at things, to discover their weirdness and terror, not their familiarity and presence. The objects and places of St. Marks, as filtered through the writing, thus evoke to us an alien landscape that persists behind the visible and familiar South Florida scenery. Every word presents us with a shadow, a dark presence that hangs behind it. What is written might be described as presented "sous rature," as Derrida might put it, referring to Heidegger's famous choice of writing Sein with an $\mathbf{x}$ over it, a gesture intended to signify that what is normally called Being (Heidegger writes "Being" is indeed the erasure of being "Being," by which we are supposed to recognize that in reading Being we are misrepresenting to ourselves what is). ${ }^{5}$ This is writing, then, that appropriately for a place whose name itself-Area $\mathrm{X}-$ suggests the notion of erasure, that cultivates omissions and allusions; writing that reminds us of dimensions of place that are absent from both the setting and from ordinary perception, and which yet constitute something like the dark presences so powerfully evoked by Lovecraft. This strange tension between the mimetic and the barred articulation of the weird real is perfectly showcased in the book's first lines :

The tower, which was not supposed to be there, plunges into the earth in a place just before the black pine forest begins to give way to swamp and then the reeds and wind-gnarled trees of the marsh flats. Beyond the marsh flats and the natural canals lies the ocean and, a little farther down the coast, a derelict lighthouse. (3)

Reading carelessly, we might feel adequately oriented by these lines. They describe a landscape, a black pine forest, a swamp, reeds and trees. We feel not only as if we are viewing a panorama of this landscape, but also as if we are reading a map, receiving indications that could potentially help us find ourselves in this place. But then there is the strange dissonance in the part about the tower. What, after all, does it mean for something to "not be supposed" to be someplace? Later we are given a partial clarification-the tower is not on the map that the explorers were given when they 
were briefed on the expedition. But this absence of the tower from the map does not annul the mystery of the object, but rather heightens it, prompting us to wonder why and how the tower was not included on maps beforehand. of course that is not the only thing that the line introduces in terms of cognitive dissonance. After all, a tower is a thing that extends up out of the ground, and yet this 'tower' is said to plunge into the earth. The tower would thus seem to be inverted, indeed to be something other than a tower, perhaps to be a tunnel, which is indeed what some of the other characters in the story do call it, albeit not the narrator. The effect of this cumulative confusion is to suggest that whatever it is does not fit with any of our names or descriptions, that it is a thing with no proper analogue in our language and no proper precursor in our past perceptions. As such, the term "tower" as well as the object to which it alludes fail to give the orientation that they seemed to offer upon a cursory reading. Instead they render the entire place a zone of disorientation, though this disorientation might be said to spring not from an absence of reality, but from an excess of the real.

The weird typography employed by Heidegger is intended to evoke the making-present of the non-present in such a way as to remind us of the consummate inadequacy of this making-present. This in turn suggests to us that the "real" Real is beyond that which is presented to us, situated in a withdrawn place that cannot be reached via the categories of language or even the categories of our perception. It does not mean that we are not aware of it, only that our versions of it are somehow pale reflections of its reality. To partially quote from another volume of VanderMeer's, it means that we "we lack the analogies" (2014 a, 523). In Annihilation, we almost constantly seem to encounter words that describe objects that do not quite fit with these words, weird or strained analogies that leave us with the general impression that they emerge not so much from a failure of descriptions to match what is seen but from a failure of the categories that structure and order our perceptions to bring the objects into full phenomenal presence. While exploring the tower/tunnel, for instance, the narrator has the bizarre experience of encountering words composed of miniscule flora and fauna. She notes that the entities that they are composed of "would have looked to the layperson like rich green fernlike moss" but she quickly makes clear that to her trained view they are "in fact" "probably" something else, "a type of fungi or other eukaryotic organism" (24). In this quick precision we immediately feel at ease, for the clarifying and orienting powers of science are at hand. But then the writing becomes weirder, and in a certain sense more realist, grasping not at the analogue of this thing and other things categorized in the past, but for this thing in its pure presence. We have a description that seems to depict the object as it is seen, but then that description seems to break down into mere metaphors, as if the object itself were deconstructing our categories: "The curling filaments were all packed very close together and rising out from the wall. A loamy smell came from the words along with an underlying hint of rotting honey. This miniature forest swayed, almost imperceptibly, like sea grass in a gentle ocean current" (24). Unlike ordinary nature writing, which in Tom Lyons's words brings about a "lifting or clarifying of perception" of the environment (Lyons 25), moving from confused observations to a precise understanding of the organization of ecosystems, this writing seems to make our perception at once muddier and more profound. In this case, the more vividly we seem to see the thing, the less sense that we have of its being clearly nameable or even identifiable. Indeed its vividness is only achieved through the negation of reference to the thing and via an allusion to a wholly other object. The muddiness and the depth of this object also go together when we 
consider it in its relation to the ecosystem as such. Making sense of these organisms depends upon our making sense of the other organisms with which they live and interact. Yet given that the tunnel includes also other unknown denizens, and depths that are unplumbed, it is the totality of the place that becomes at once more present and more obscure and horrifying in the encounter with these weird letters.

VanderMeer's narrator is a biologist and at many times in the text she looks at the world through a scientific perspective. Yet what scientists do to create order is to impose limits, separating the known and knowable from the unknown and irrelevant. Ecologist and nature writer George Haskell, for instance, decides to study what he calls a "mandala," a circle in the forest in order to make sense of the larger forest itself. As Haskell explains, "I believe the forest's ecological stories are all present in a mandalasized area... the truth of the forest may be more clearly and vividly revealed by the contemplation of a small area than it could be by donning ten-league boots, covering a continent..." (Haskell xi). While it may be well and true that conceptual clarity is achieved through such delimitation, it is also true that limits marking place are always arbitrary. They are always either geometric abstractions that have nothing to do with the lived being of the place (as is the case with the perfectly circular and self-evidently spiritual Mandala, or with a political demarcation cut along a line of latitude or longitude), or, if they are rooted in ecotopes or bioregions such as the Pacific Northwest as seen by Gary Snyder, they are to a certain degree undefined. Do we know, for instance, when a swamp ecosystem ends and a beach ecosystem begins? Is it the last Douglas Fir that marks the end of the ecosystem of the Douglas Fir, or, rather, are the limits marked by the last insect that exists in a symbiotic relationship with this tree? And what about the other beings that exist in relationship to that insect? Where is the absolute point of transition? These are questions that we could pose about the ontological status of our scientific knowledge of the real ; these are questions explicitly generated by the weird character of VanderMeer's Area X, which paradoxically is said to be composed of all transitional ecosystems. That is to say, ecosystems that are neither of one or another sort, ecosystems that are somehow of two kinds at once and which are neither at once, ecosystems that confront us with the multiplicity of the real in its disorder rather than a reduction of this real into order via artificial delimitations and interpretative frameworks.

It is perhaps then a commitment to irreductionism that is most evident in VanderMeer's descriptions of Area X. His writing does not so much strive to exhaust all of the details of the surroundings, nor repeatedly re-articulate the same details (as in the text quoted above which describes obsessively the thistle), but rather strives to speak about this world while perpetually reminding us that what we see is a reduction of the real to an instrumentalized and partial version of the same. VanderMeer articulates perfectly the tension between knowledge as reduction, and the wonder of the pure if also obscure presence, in an episode in which the biologist, before her coming to Area X, encounters the aptly named "destroyer of worlds" starfish. Staring down at this real but seemingly alien creature, the narrator finds that the longer she stares, "the less comprehensible the creature became". It transforms into "something alien," that gives her the "sense" that she "knew nothing at all- about nature, about ecosystems. There was something about my mood and its dark glow that eclipsed sense, that made me see this creature, which had indeed been assigned a place in the taxonomy- catalogued, studied, and described- irreducible down to any of that" (175). My interest in this passage derives from the connection between this falling away 
of all that makes sense, all that makes up our ordered cosmos and indeed our world, and the encounter with the pure obscurity and intensity of the starfish. This is an incredibly rare event, for as Heidegger has reminded us, we almost always experience things as objects known and oriented around us as subjects. We do not hear "noise" and "complexes of sound" but rather "the column on the march, the north wind, the knocking of the woodpecker, and the crackling fire" (Heidegger 2001, 163). It is rare, almost impossible, to have these sorts of breakdowns without a destroyer of worlds, an alien thing that ruptures our tranquility and finally shatters our subjectivity, or, perhaps, what would be better put, our Da-Sein, our being there. This alien can just be another, an Other being whose world we take to be real, at least as real as our own, but which we recognize that we do not share, that we cannot share, and that therefore we must weirdly or awkwardly co-inhabit with. It can also be, and is for Heidegger, the work of art, that thing that creates a tear or gap or Ri $\beta$ in being. It is, for horror, that zone in the interior of the enchanted circle, that weird place where all that is horrifying happens.

The biologist-narrator follows up her reaction to the starfish by reflecting on herself : "And if I kept looking, I knew that ultimately I would have to admit I knew less than nothing about myself as well, whether that was a lie or the truth" (175). The word Dasein, for Heidegger, is synonymous with the being of the human, but it also articulates a sense of being that is always situated, always in a place, and only capable of coming to knowledge of the self in combination with a coming to awareness of the nature of that place. As Jeff Malpas has explained, summarizing much of what he has elaborated upon in his work on Heidegger's topology :

Subjectivity cannot be grasped independently of a larger structure that encompasses other subjects as well as the objects and events of the world. It is, we can say, in the dense structure of place that subjectivity is embedded and, inasmuch as subjectivity is only to be found within such a structure, so there is a necessary dependence of subjectivity on the other elements within that structure and on the structure as it whole." (Malpas 2009, 175)

The encounter with the weird real thus brings about the dissolution of the subject, a collapse or foundering of self-knowledge. But if this is all the case, then the weird real also makes us conscious, as in the lines above, of the fact of our consciousness as reductive. It is hence in itself a thing of danger to our ecological well being, since it is productive of an illusory knowledge of place, where the reality itself lies further outside.

31 This is exactly the trap that is encouraged by nature writing and indeed by much of ecological philosophy. When we strive to render ourselves conscious of the ways in which we are bound up in this world, following nature writers and certain ecophenomenologists such as David Abram, we may feel that we have replaced a more typical or alienated opposition between subjects and objects with one in which humans and things are tightly bound in relationships of mutual co-implication. Abram, for instance, claims in his Becoming Animal that we can attain such an attunement that "our bodies resonate with one another and with the other rhythms that surround us" (Abram 11). Yet at best, such an attunement amounts to so perfect an integration into the world of the "there" that the withdrawn or obscure is forgotten. We might have become the world, but the world here is only the one that we encounter, and it is thus conditioned and diminished by the limits of human embodiment and human subjectivity. The gaps or holes in being, with their alienation of the subject from its 
being there, are forgotten, as if they were not, in fact, there. Yet there are other bodies, and as such other sensual worlds, parts of the world that are real without being us.

Perhaps the limits of the naturalistic real must correspond to the limits of our bodies, but the bounds of the real as such must include the possibility of thinking other sorts of embodied worlds as sharing the background with us. It is this possibility of experiencing what might be described as alterioembodiment and alterioperception that occurs in Area X. Not only does the encounter with the place break down the subject, drawing the subject into a madness that derives from contact with the real (as in Lovecraft), but the subject is also reconstituted in a new way, and in a new relationship to the real, because the being there of the subject is different, diffused outside of the body and into the environment, such that the sensual contact with the world, the being-there, is not situated within one body but diffused amongst multiple differentlyembodied bodies, while at the same time remaining tied to the original body, only now in a risible or weird way. The biologist writes of being able to "feel the shifting of the surveyor's hips as she lay against the ground," and that is to say that it was as if the ground were not something that supported her own body but was rather her body itself, a feeling and experiencing body. She speaks also of "tasting the yellow grass" that the surveyor has crushed beneath her, of "hearing the sweat" (150) dripping down her face. At this point it is less clear where and in what avatar body this alteriosensuality is situated, or even what kind of a body would be necessary to experience such sensations. What is clear is that the narrator is no longer a there-being (a Da sein) bringing the environment to expression, but rather the environment as a series of variably and incommensurably embodied beings finds itself channeled through one voice, a kind of around or Umsein (the German word for environment is Umwelt). Such a weird subjectivity is of course disorienting, rather than seeing or feeling oneself as discrete and yet connected to a pole or a there within being, this Umself embraces multiple and incommensurate places at once, experiencing at one and the same time limits and worlds beyond those limits, void and fullness madly and dissonantly overlapping.

\section{On Weird Realism and the Future of Ecology}

"Looking out over that untroubled landscape, I do not believe any of us could yet see the threat." (VanderMeer 2014 b, 3)

These words, taken from the beginning of Annihilation, could be used to describe any number of vistas and places participating in the ongoing crisis of the Anthropocene. "It was a lovely neighborhood in a quiet residential area, with lots of trees and lots of children outside playing. It seemed just the place for our family" (Gibbs 40), wrote Lois Gibbs of the superficial appearance of the neighborhood around the infamous Love Canal. Tom's River, New Jersey, the site of an enormous pollution-caused cancer cluster, is described by Dan Fagin as "no different from thousands of other towns" (Fagin xiv). Allen Weisman, when visiting Chernobyl, found himself discombobulated by the experience of seeing birds-"barn swallows"-"zipping naked around the carcass of the hot reactor" (Weisman 214), as if nature itself was going on normally despite the disaster. His point was to emphasize that nature has the power to reclaim the world after we are gone, but a more uncanny point might be made here, namely that the 
world we live in is getting ever weirder, the disconnections between our felt experiences of places and their deeper realities ever more gaping.

Timothy Morton (2013) has thus described ours as the Age of Asymmetry. What he means by this is that we have suddenly entered an epoch where the gap between appearances and realities has grown to the point that we no longer understand the world of the senses as the real world, but rather as a cover over another world of depths that we can fathom with science. That is to say that our lives are more and more oriented around responding to dimensions of reality that do not form part of Nature, at least insofar as Nature corresponds to the world of our situated senses and ordinary perceptions. Consider, for instance, the gap between climate and weather. Weather, as everyone knows, is a local and temporally situated phenomenon, the state of sun, rain, heat or cold at a particular moment and place. Climate is something different; it is something tacked together out of statistical averages and rendered apparent to us only via extraordinarily complex mathematical models. We can see weather, and we perhaps have an intuitive grasp of climate, in the sense that we are approximately aware of the changes in the seasons and the normal variability of weather in any particular location. Yet global climate is not something that we can see, and we indeed have a very difficult time placing ourselves, and placing where we find ourselves within global climate change. It is too weird, too dissonant with our perceptions, not to feel lost when acknowledging that the incredible volume of snow that fell on the East Coast of the United States during the winter of 2013-14 was a function of global warming. Climate change, to be precise, is a black box phenomenon in that our access to it is mediated through complicated computer models, like so much of science, according to Bruno Latour. Perhaps some scientists understand the models, though for most of us we only understand the predictions. Yet as terrifying as these predictions are, more terrifying still (or perhaps calming for the climate deniers) is the fact that these models of climate themselves are, as NASA climatologist Gavin Schmidt has noted, "not right or wrong; they're always wrong," they are always "approximations," always "reductions" (Schmidt 2014).

The Age of Asymmetry comes after the end of the world. That is to say that we who live in the Anthropocene no longer find ourselves capable of believing in the innocence of the sensual world that surrounds us. Our world has become weird, our reality horrifying. We are too aware that the apparent nothing that comes out of our cars when we start them is accumulating in infinitely minute particles in the atmosphere. Unlike the soot and smog that threatened our major cities as far back as the $19^{\text {th }}$ century, prompting cries of alarm from William Blake and other Romantic Poets, carbon dioxide is invisible. We cannot see the upwards of $400 \mathrm{ppm}$ of carbon dioxide and other greenhouse gasses that currently exist in our atmosphere. Nor can we situate this pollution, for the global climate is just as threatened by those invisible particles in the most pristine regions of the Canadian North as it is in the visibly smoggy streets of Shanghai. Yet even where air pollution is concerned, weirder, deeper realities intrude into our awareness. According to scientists, it is not the larger, visible pollutants that are the most carcinogenic, but rather the infinitesimally small nanoparticles. Thus our cities may seem to be visibly less polluted than in the past, but they may actually be just as dangerous to our health while simultaneously seeming cleaner. A similar worldshattering tension between apparent health and purity versus death-dealing reality is present in many ordinary household objects. Consider the case of BPA, a form of plastic 
widely used in the $20^{\text {th }}$ century for the fabrication of items such as baby bottle nipples. Originally considered ideal for this application because of its translucency (a signal of purity according to our senses), this material was later discovered to be a potent endocrine disruptor (Cicolella 1963). Today, tests show that $93 \%$ of the population have traces of BPA in their systems, and because of this our societies are seeing an augmentation of the number cases of breast and prostate cancer, a decline of male sperm quality, early pubescence in girls, metabolic disorders such as diabetes and obesity, and behavioral disorders such as hyperactivity and ADHD.

Living in the Anthropocene implies that we are no longer at home, or that our home is no longer comfortable but filled with terrors and depths that are perhaps best captured by the metaphysics of the weird that we have uncovered in our explorations of weird fiction. Living in the Anthropocene implies not only that we are aware that the world has dimensions that exceed the grasp of our senses, but also that there are dimensions or depths to the real that exist beyond even those of science. Despite all of the efforts taken by weird writers to resist reducing the real, despite all of their wars against language and geometric space, weird writing is always in the end naturalized, and that is to say retuned to the world of reason, order, and anthropomorphically ordered representations, if only in the inverted sense of presenting us with the supernatural. Doubtless the supernatural is no more the real than the Natural, and perhaps the problem with horror is that it may tend to produce a kind of paralysis and existential nihilism within its readers, in the way that a blood-curdling scream can freeze us in our tracks. But given our society's tendency to lapse into close-minded ignorance, particularly towards ecological problems, I am hardly sure that this is a bad thing, though the question of ecological nihilism, which is not identical with our society's present but disavowed desire for ecocide, merits further discussion.

The horror of the Anthropocene and the real of weird realism remind us of the inutility of trying to naively suture together the real and the Natural, even if this is clearly the ambition of most place-based writing and critical studies thereof. The weird expressionism of horror, in its striving to express the unnamable while leaving it dark, at least leads us towards a real appreciation of the difficulty of thinking and representing places, and indeed towards an appreciation of the way in which overlooking this difficulty fuels the destructive tendencies in our civilization. If ecology is the study of organisms and their relations to their environments-relations between objects and the other objects composing places around them-then being a realist ecologist is being sensitized to that which not only is visible but which is also withdrawn or wholly other; that which is reality but also ungraspable within all naturalist accounts of the ambient world. While one might question the utility of this realism, noting that we only blindly touch upon the real and only then via the help of fiction and the imagination, reading weird realist writings and criticism teaches us to look for the overlooked (and not just to look at the overlooked). Re-encountering familiar scenes after having read horror is to see these scenes with heightened senses, with an awareness of straining for sight beyond sight. Thus the weird hardly leads us away from the places in which we dwell. On the contrary, it brings us back to them with $\mathrm{x}$-ray attentiveness and extraordinary humility. 


\section{BIBLIOGRAPHY}

Abram, David. The Spell of the Sensuous. New York : Vintage, 1997.

Bonneuil, Christophe and Jean-Baptiste Fressoz. L'Événement Anthropocène. La Terre, l'histoire et nous. Paris : Seuil, 2013.

Cicolella, André. Toxique Planète : Le scandale invisible des maladies chroniques. Paris : Seuil, 2013.

Clark, Andrew. Being There : Putting Brain, Body, and World Together Again. Cambridge MA : Bradford Books, 1998. Kindle Edition.

Emerson, Ralph Waldo. Essays - Second Series. Public Domain, 2011. Kindle Edition.

Fagin, Dan. Tom's River : A Story of Science and Salvation. New York : Bantam, 2013.

Friedman, Rob and Karen Waldron. Towards a Literary Ecology : Places and Spaces in American Literature. Lanham, MD : Scarecrow, 2013.

Gibbs, Lois Marie. Love Canal : My Story. Albany : SUNY Press, 1982.

Hadot, Pierre. Le Voile d'Isis : Essai sur l'histoire de l'idée de Nature. Paris : Gallimard, 2004.

Harman, Graham. Guerrilla Metaphysics : Phenomenology and the Carpentry of Things. New York : Open Court, 2005.

---. Weird Realism : Lovecraft and Philosophy. Winchester : Zero, 2012.

Haskell, David George. The Forest Unseen : A Year's Watch in Nature. New York : Penguin Group, 2012. Kindle.

Heidegger, Martin. Ernst Jünger, Martin Heidegger : Briefwechsel Briefe 1949-1975. Stuttgart : KlettCotta, 2008.

---. Sein und Zeit. Tübigen : Max Niemeyer, 2001.

--- “Bauen, Wohnen, Denken.” Vorträge und Aufsätze. Stuttgart : Klett-Cotta, 2009.

Hoffmann, E.T. A.. Der Sandmann. Stuttgart : Reclam, 1986.

Hume, David. Inquiry Concerning the Principles of Human Understanding. Oxford : Oxford University Press, 1999.

Joshi, S.T.. The Modern Weird Tale. New York : McFarland, 2001.

Kant, Immanuel. Kritik der reinen Vernuft. Hamburg : Felix Meiner, 1998.

Kohn, Eduardo. How Forests Think: Towards and Anthropology Beyond the Human. Berkeley : University of California Press, 2013.

Latour, Bruno. Cogitamus : Six lettres sur les humanities scientifiques. Paris : La découverte, 2010.

---. Politiques de la nature. Paris : La Découverte, 1999.

Ligotti, Thomas. Conspiracy Against the Human Race. New York: Hippocampus, 2012.

Lovecraft, H. P. Necronomicon. New York : Orion, 2008. Kindle.

---. Supernatural Horror in Literature. New York : Dover, 1973.

---. “The Defence Remains Open !” (1921), Miscellaneous Writings, ed. S. T. Joshi. Sauk City, WI : Arkham House, 1995. 
Lynch, Tom and Cheryl Glotfelty. Armbruster, Karen. The Bioregional Imagination : Literature, Ecology, and Place. Athens : University of Georgia Press, 2012.

Lyons, Tom. The Incomparable Land. Minneapolis : Milkweed, 2001.

Malpas, Jeff. Place and Experience : A Philosophical Topography. Cambridge : Cambridge University Press, 2009. Kindle.

Morton, Timothy. Ecology Without Nature : Rethinking Environmental Aesthetics. Cambridge MA : Harvard University Press, 2009.

---.Hyperobjects : Philosophy and Ecology After the End of the World. New York : University of Minnesota Press, 2013.

---. The Ecological Thought. Cambridge MA : Harvard University Press, 2010.

Poe, Edgar Allen. The Complete Edgar Allen Poe Tales. London : Guild, 1984.

Royle, Nicolas. Veering: A Theory of Literature. Edinburgh : Edinburgh University Press, 2012.

Scheese, Don. Nature Writing: The Pastoral Impulse in America. London : Routledge, 2002.

Schopenhauer, Alfred. Parerga und Paralipomena I. Berlin : Diogenes, 2007.

Schmidt, Gavin. “The Emergent Patterns of Climate Change.”June 1, 2014. http://www.ted.com/ talks/gavin_schmidt_the_emergent_patterns_of_climate_change/transcript

Sellars, Wilfred. Science, Perception, and Reality. New York : Humanities Press, 1963

Snyder, Gary. The Gary Snyder Reader. Berkeley : Counterpoint, 1999.

Sparrow, Tom. Levinas Unhinged. Winchester : Zero Books, 2013. Kindle.

Thacker, Eugene. In the Dust of this Planet. Winchester : Zero Books, 2011.

Vandermeer, Jeff. Acceptance. New York : Farrar, Straus \& Giroux, 2014. Kindle.

---. Annihilation. New York : Farrar, Straus \& Giroux, 2014.

---. “Annihilation : 'Weird' Nature.” Weird Fiction Review. WeirdFictionReview.com, 04 Feb. 2014. http://weirdfictionreview.com/2014/02/annihilation-weird-nature/

Von Uexkull, Jakob. A Foray into the Worlds of Animals and Humans : with A Theory of Meaning. Duluth : University of Minnesota Press, 2010.

Weisman, Alan. The World Without Us. New York : Saint Martins, 2007.

\section{NOTES}

1. In a recent article VanderMeer has described his work as "weird nature writing," a generic description that I am tweaking here.

2. On the Anthropocene, both as a notion as a phenomenon, see Bonneuil and Fressoz's excellent L'événement anthropocène: La Terre, l'histoire et nous, as well as Timothy Morton's Hyperobjects: Philosophy and Ecology after the End of the World

3. Heidegger talks about these two notions in several places, though perhaps most prominently in his pivotal essay, "Bauen, Wohnen, Denken".

4. Lovecraft once insisted that the "crux of a weird tale is something which could not possibly happen. If any unexpected advance of physics, chemistry, or biology were to indicate the possibility of any phenomena related by the weird tale, that particular set of phenomena would cease to be weird in the ultimate sense because it would become surrounded by a different set of 
emotions" (Lovecraft 1973, 8). His point here is not that physics, chemistry, and biology cannot be used within the weird tale, but rather that the ultimate reality explored by the weird tale lies beyond this beyond.

5. Heidegger first introduces and most extensively theorizes this point in an essay to Ernst Jünger dedicated to the theme of nihilism. Here he writes that the this "crossways striking through" of the word is meant to suggest the "almost unbreakable habit" of seeing "Being" as a "thing standing standing by itself then approaching humankind," a bit later he will clarify this by suggesting that this correlates with an alienated relationship to being, one appropriate to the tension between humanity and Being-nihilism-that correlates with Being as it is "conceived of through the subject-object relation" (Heidegger 2008, 179). A precision relative to my own usage of the word in what follows is necessary. While Heidegger's primary interest is in forcing us to recognize representation's role in distancing us from a Being that would be ours, our usage of the term cuts in the opposite direction, signaling the tendency to think of Being as representation ("Being") as a being that also and likewise obscures the independent and autonomous Being of objects. This Being is likewise ignored by the metaphysics of presence, if it is also, and systematically, ignored by Heidegger (if it has been recuperated for philosophy by Graham Harman's (2005) work on Heidegger).

\section{ABSTRACTS}

This article deals with the generally underestimated importance of horror fiction for eco-critical thinking about place. It looks at three major horror writers, Poe, Lovecraft, and VanderMeer, exploring the ways that each plays with and deepens our understanding of what it means to be in a place. Contrary to popular opinion, which would claim that horror writers both use stock backgrounds, and in any case deal only with fictions, I argue that horror fiction is in many ways more realist than other forms of writing, and as such deserving of far more critical attention than it has thus far been accorded by eco-critics.

Cet article traite de l'importance généralement minorée du roman d'horreur dans la réflexion sur la notion de lieu au sein de la pensée écocritique. Il observe la façon dont trois écrivains importants du roman d'horreur: Poe, Lovecraft, et VanderMeer, jouent avec notre compréhension de la notion du lieu tout en l'approfondissant. Contrairement à la plupart des éco-critiques, qui ne voient dans le roman d'horreur que des rapports très superficiels avec l'environnement, ou plutôt une tendance à la fiction pure, je soutiens que le roman d'horreur est, d'une certaine manière, beaucoup plus réaliste que d'autres formes de récits et, que partant, il mérite plus d'attention que ne lui en ont accordé les éco-critiques jusqu'à présent.

\section{INDEX}

Mots-clés: horreur, écologie, lieu, ontologie centrée sur l'objet

Keywords: horror, ecology, place, object-Oriented Ontology 
AUTHORS

BRAD TABAS

Instructor

Paris College of Art

tabasbrad@gmail.com 